\title{
Electrophysiological Properties of Neuroendocrine Cells of the Intact Rat Pars Intermedia: Multiple Calcium Currents
}

\author{
Peter J. Williams, Brian A. MacVicar, and Quentin J. Pittman \\ Neuroscience Research Group, University of Calgary, Calgary, Alberta, Canada T2N 4N1
}

Intracellular recordings for current and voltage clamping were obtained from 130 neuroendocrine cells of the pars intermedia (PI) in intact pituitaries maintained in vitro. Spontaneous and evoked action potentials were blocked by TTX or by intracellular injection of a local anesthetic, QX-222. After potassium $\left(\mathrm{K}^{+}\right)$currents were blocked by tetraethylammonium (TEA), 4-aminopyridine, and intracellular cesium $\left(\mathrm{Cs}^{+}\right), 2$ distinct calcium $\left(\mathrm{Ca}^{2+}\right)$ spikes were observed which were differentiated by characteristic thresholds, durations, and amplitudes. Both $\mathrm{Ca}^{2+}$ spikes were blocked by cobalt $\left(\mathrm{Co}^{2+}\right)$ but were unaffected by TTX or QX-222. The lowthreshold spike (LTS) had a smaller amplitude and inactivated when membrane potential was depolarized past $-\mathbf{4 0}$ $\mathrm{mV}$ or when evoked at a fast rate $(>0.5 \mathrm{~Hz})$. The high-threshold spike (HTS) typically had a larger amplitude and longer duration, was not inactivated at potentials which inactivated the LTS, and could be evoked at rates of up to $10 \mathrm{~Hz}$.

Single-electrode voltage-clamp analysis revealed that 3 distinct components of the $\mathrm{Ca}^{2+}$ current were present in most cells. From a negative holding potential ( $-90 \mathrm{mV}), 2$ separate peak inward currents were observed; a low-threshold transient current, similar to a T-type $\mathrm{Ca}^{2+}$ current, activated at $-\mathbf{4 0} \mathrm{mV}$, whereas a large-amplitude inactivating current activated above $-20 \mathrm{mV}$. This large inactivating $\mathrm{Ca}^{2+}$ current was significantly inactivated at a holding potential of -40 $\mathrm{mV}$ or by brief prepulses to positive potentials, and was similar to an $\mathrm{N}$-type $\mathrm{Ca}^{2+}$ current. $\mathrm{A}$ sustained $\mathrm{Ca}^{2+}$ current (L-type) was observed which was not altered by different holding potentials. The T-type current most likely underlies the LTS and a combination of the $\mathrm{N}$ - and L-types most likely underlies the HTS.

The pituitary pars intermedia (PI) is a useful preparation for the analysis of the electrophysiological properties of neuroendocrine cells because it represents a population of cells which secrete $\alpha \mathrm{MSH}$ and endorphin-related peptides (Goldman et al., 1983). Most of the electrophysiological analysis of these cells has been performed in tissue culture, and it has been shown that dissociatcd PI cclls, in tissuc culture, havc both sodium $\left(\mathrm{Na}^{+}\right)$ and calcium $\left(\mathrm{Ca}^{2+}\right)$ spikes (Douglas and Taraskevich, 1980, 1982).

\footnotetext{
Received May 18, 1989; revised Aug. 24, 1989; accepted Sept. 27, 1989.

This work was supported by Medical Research Council of Canada. P.J.W is an Alberta Heritage Foundation for Medical Research student; B.A.M. and Q.J.P. are AHFMR Scholars and MRC Scientists. Thanks to Laurel Franklin and Stephanie Crichton for technical assistance.

Correspondence should be addressed to Peter J. Williams, Medical Physiology, University of Calgary, 3330 Hospital Dr. NW, Calgary, Alberta, Canada T2N $4 \mathrm{~N} 1$.

Copyright $(C) 1990$ Society for Neuroscience $0270-6474 / 90 / 030748-09 \$ 02.00 / 0$
}

One analysis of $\mathrm{Ca}^{2+}$ currents in PI cells in tissue culture has shown 2 currents with different thresholds and inactivation rates (Cota, 1986). Another report indicated that cultured PI cells may have 3 different $\mathrm{Ca}^{2+}$ currents (Taleb et al., 1986), apparently corresponding to the $\mathrm{T}$-, $\mathrm{N}$-, and L-type currents described by Tsien and coworkers (Nowycky et al., 1985; Fox et al., 1987a, b). It is important, however, to examine the electrophysiological properties of PI cells that have not been cultured to insure that they are not significantly affected by culture conditions. This is particularly pertinent considering a recent study which reported changes in $\mathrm{Ca}^{2+}$ currents in PI cells over several days in culture (Cota and Armstrong, 1987). We have developed an intact pituitary preparation for the electrophysiological analysis of PI cells (MacVicar and Pittman, 1986). A particularly important advantage of the intact pituitary is that we can analyze the effects of synaptic inputs onto these cclls because the pituitary stalk is still intact and afferent fibers can be activated. Previously, we have analyzed the effects of synaptic activation of GABAergic or dopaminergic fibers synapsing on these neuroendocrine cells (Williams et al., 1989a, b). In this study we have used current and voltage-clamp techniques to examine some electrophysiological properties of PI cells and in particular, to describe their $\mathrm{Ca}^{2+}$ currents. A definition of these electrophysiological properties is necessary for our continuing analysis of alterations of PI cell properties by neurotransmitters (Williams et al., $1989 \mathrm{~b}$, 1990).

\section{Materials and Methods}

Pituitaries were obtained from male Sprague-Dawley rats (250-300 gm). Under ether anesthesia, rats were decapitated and the skull and brain overlying the pituitary were dissected free. Care was taken to cut the pituitary stalk before it was damaged by movement of the overlying brain. The pituitary with the remaining stalk was then dissected free of the sella turcica in the base of the skull. It was next placed in a recording chamber which was maintained at $35^{\circ} \mathrm{C}$ and superfused at $2 \mathrm{ml} / \mathrm{min}$ with physiological solution containing (in $\mathrm{mm}$ ): $\mathrm{NaCl}, 124 ; \mathrm{KCl}, 5$; $\mathrm{MgCl}_{2}, 1.3 ; \mathrm{NaHCO}_{3}, 26$; glucose, $10 ; \mathrm{CaCl}_{2}, 2$; and oxygenated with $95 \% \mathrm{O}_{2} / 5 \% \mathrm{CO}_{2}$. The pituitary was held lightly in place with wire probes positioned by a micromanipulator. Recordings could be obtained immediately after placement in the recording chamber, and viable cells were still present up to $4 \mathrm{hr}$ after the pituitary was removed from the animal.

The PI was readily identified under the dissecting microscope as a distinct pale band surrounding the posterior pituitary and scparating it from the more vascularized anterior pituitary (Fig. 1 $A$ ). Microelectrodes were visually guided to the PI. In 5 experiments, cells were injected with Lucifer yellow (0.2-0.5 nA hyperpolarizing current for $2-5 \mathrm{~min}$ ) in order to verify that the recordings were indeed being obtained from the PI. After injection the pituitary was fixed in formaldehyde $(4 \%$ in $0.1 \mathrm{M}$ phosphate buffer, $\mathrm{pH} 7.4$ ). The whole pituitary was dehydrated in a graded ethanol series, cleared in methyl salicylate, and observed using a Zeiss epifluorescence microscope. Cells injected with Lucifer yellow had a cuboid appearance (approximately $12-15 \mu \mathrm{m}$ diameter), and they 

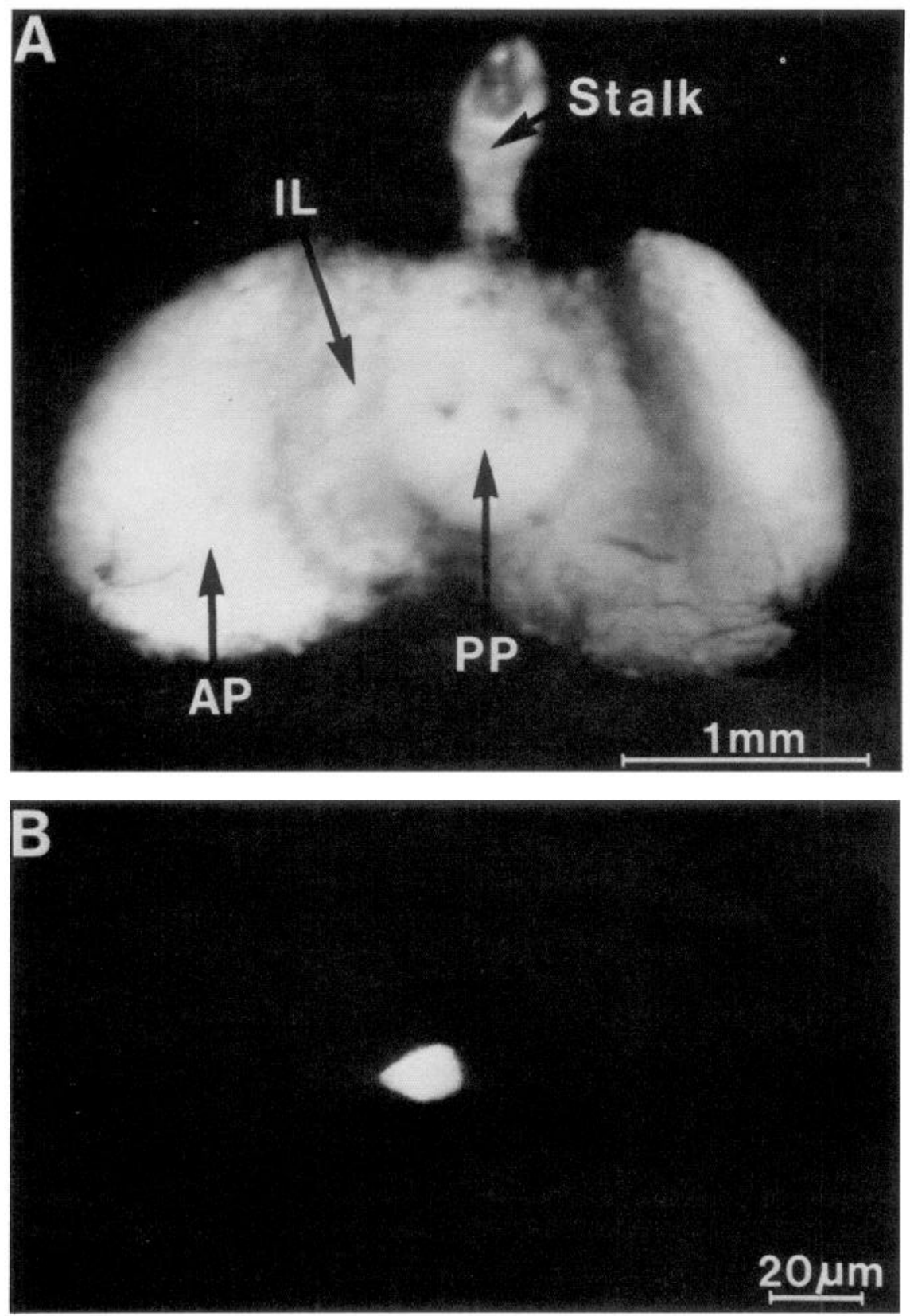

Figure 1. A, View of the intact pituitary from its dorsal aspect upon removal from the animal. The intermediate lobe $(I L)$ is clearly distinguishable as a relatively avascular region between the anterior $(A P)$ and posterior $(P P)$ lobes. The cut end of the pituitary stalk (Stalk) is retained in this preparation and allows stimulation of afferent fibers innervating the intermediate lobe. $B$, Photomicrograph of a Lucifer yellowinjected melanotroph in the intact pituitary. Note the lack of processes and of coupling to other cells.

never displayed processes or exhibited dye coupling ( $n=5$, Fig. $1 B$ ). All injected cells were localized to the PI.

Intracellular microelectrodes $(80-100 \mathrm{M} \Omega$ ) were made from thin-wall capillary glass ( $1.5 \mathrm{~mm}$ with filament) and were filled with one of the following solutions: (1) $0.5 \mathrm{~m}$ potassium $\left(\mathrm{K}^{+}\right)$acetate; (2) $0.5 \mathrm{M} \mathrm{K} \mathrm{K}^{+}$acetate and $1 \mathrm{~mm}$ QX-222; (3) $0.5 \mathrm{M}$ cesium $\left(\mathrm{Cs}^{+}\right.$) acetate; or (4) $0.5 \mathrm{M} \mathrm{Cs}^{+}$ acetate plus $1 \mathrm{~mm}$ QX-222 plus $50 \mathrm{~mm}$ tetraethylammonium (TEA) acetate. Recordings were amplified with an intracellular amplifier from the Department of Neurophysiology, University of Copenhagen, or an Axoclamp from Axon Instruments and were stored either digitized on a VCR tape system or on an IBM-AT using the PCLAMP analysis system (Axon Instruments). Experiments involving voltage-clamp analysis of $\mathrm{Ca}^{2+}$ currents utilized the Axoclamp in the single electrode switching clamp mode. Switching frequency was $2-2.5 \mathrm{kHz}$. The clamp parameters were optimized using $10 \mathrm{msec}, 10 \mathrm{mV}$ square-wave command pulses, and clamp performance was monitored using an oscilloscope to display unfiltered headstage output throughout the experiments. Voltage command pulses were generated using the PCLAMP software system running on the IBM-AT computer. This system was also used for the analysis of waveforms and leak current subtraction. In order to confirm that the currents being analyzed were in fact due to $\mathrm{Ca}^{2+}$, and to account for nonlinearities in leak current, all experiments were performed first in control solution and then in solution containing $1 \mathrm{mM}$ cobalt $\left(\mathrm{Co}^{2+}\right)$ chloride. Currents obtained in the presence of $\mathrm{Co}^{2+}$ were then subtracted from those obtained in control solution so that the currents measured and reported here are only those abolished by $\mathrm{Co}^{2+}$.

4-Aminopyridine (4-AP) and TEA were obtained from Sigma (St. Louis); all other salts were obtained from Fisher Scientific (Fair Lawn, NJ). QX-222 was a gift of Astra Pharmaceuticals (Westboro, MA). Drugs were stored as stock solutions and protected from light until they were dissolved in the perfusate immediately before use.

\section{Results}

After the cells were initially impaled with the microelectrode, they were hyperpolarized by current injection until the recording was stable and the cell "sealed." After this period of stabilization, the resting membrane potential in the absence of holding current ranged from -35 to $-50 \mathrm{mV}$. The input resistance of 

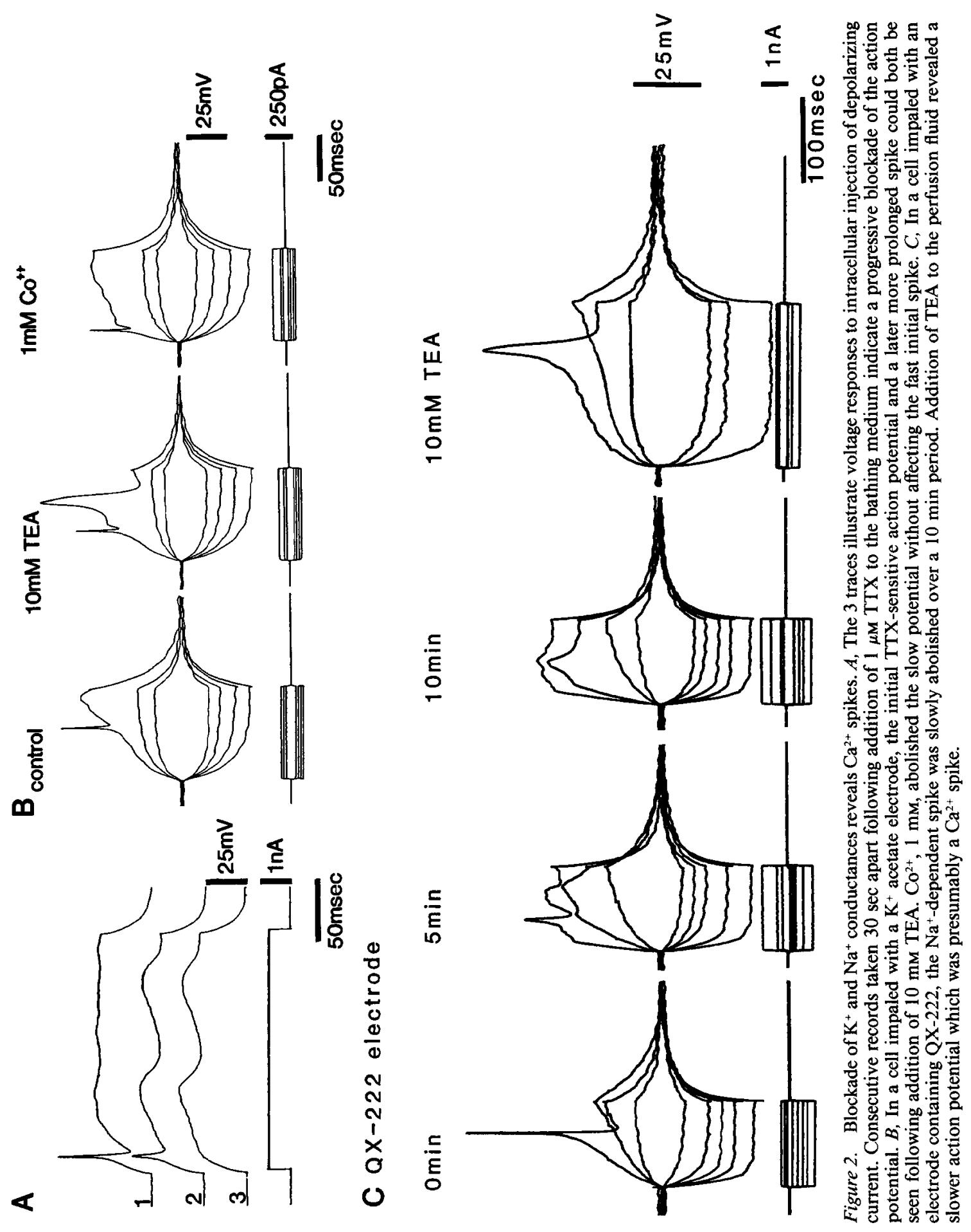


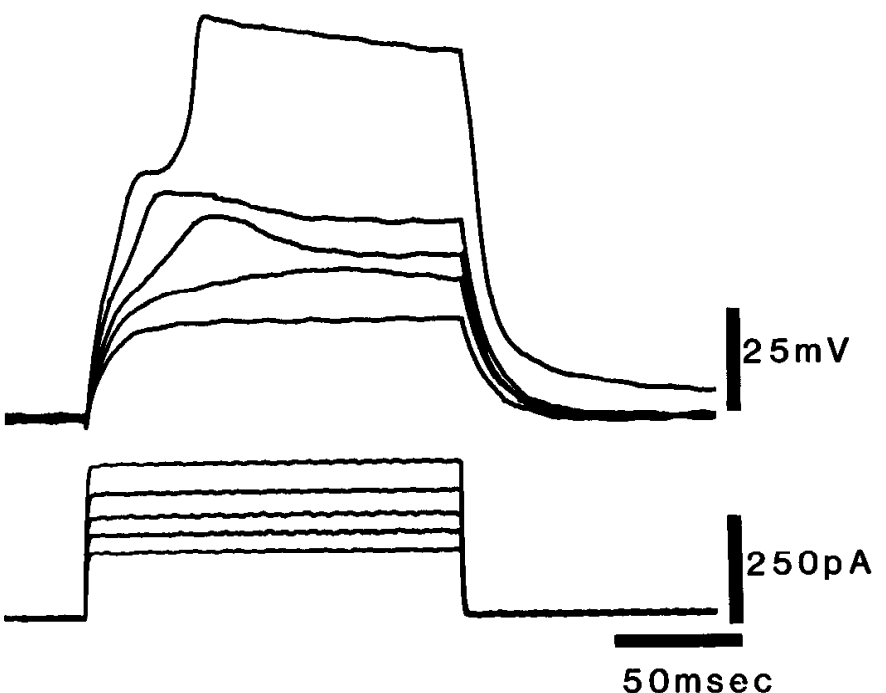

Figure 3. Multiple $\mathrm{Ca}^{2+}$ conductances in the melanotroph. In a cell impaled with an electrode containing TEA, $\mathrm{Cs}^{+}$acetate, and QX-222 and with 4-AP in the extracellular medium, $2 \mathrm{Ca}^{3+}$ potentials can bc seen. From a holding potential of $-80 \mathrm{mV}$, the injection of brief current pulses (lower trace) activated a transient potential with a threshold at about $-40 \mathrm{mV}$ (low-threshold spike, LTS). Larger current pulses to potentials above $0 \mathrm{mV}$ produced a noninactivating plateau potential (high-threshold spike, HTS). the cells ranged from $200 \mathrm{M} \Omega$ to $2 \mathrm{G} \Omega$ with a mean of $440 \mathrm{M} \Omega$. In approximately $10 \%$ of the cells studied, spontaneous action potentials were observed. The remaining cells were quiescent, but action potentials could be evoked by current injection.

Action potentials in control solution were predominantly $\mathrm{Na}^{+}$ dependent, as they could be blocked by the addition of TTX (1-3 $\mu \mathrm{M})$ (Fig. 2A). When action potentials were evoked following the addition of the $\mathrm{K}^{+}$channel blocker TEA (10 mM) to the solution bathing the tissue, an initial fast action potential was seen followed by a broad spike with a pronounced afterhyperpolarization (Fig. $2 B$ ). The broad spike was abolished by $1 \mathrm{~mm}$ $\mathrm{Co}^{2+}$, suggesting it is due to a $\mathrm{Ca}^{2+}$ conductance. When a cell was impaled by an electrode containing QX-222, a local anesthetic (Puil and Carlen, 1984), the $\mathrm{Na}^{+}$-based action potential rapidly declincd and was totally abolished within $10 \mathrm{~min}$ (Fig. $2 C$ ). Subsequent addition of $10 \mathrm{~mm}$ TEA again resulted in the appearance of $\mathrm{a} \mathrm{Ca}^{2+}$ spike. Similar results were obtained in 20 other cells.

In order to study $\mathrm{Ca}^{2+}$-based action potentials in isolation, $\mathrm{Na}^{+}$and $\mathrm{K}^{+}$conductances were abolished by the use of electrodes containing $0.5 \mathrm{M} \mathrm{Cs}^{+}$acetate, $50 \mathrm{~mm}$ TEA acetate plus $1 \mathrm{~mm}$ QX-222 and by the addition of $0.5 \mathrm{~mm}$ 4-AP to the extracellular solution. When $\mathrm{Na}^{+}$and $\mathrm{K}^{+}$conductances were blocked in this way, 2 stinct $\mathrm{Ca}^{2+}$ spikes were revealed (Fig. 3). One small transient potential (low-threshold spike, or LTS) was elicited by pulses to $-40 \mathrm{mV}$ from a holding potential of $-80 \mathrm{mV}$. A second, high-threshold spike (HTS) was activated with a threshold at $-20 \mathrm{mV}$. Neither the HTS nor LTS was abolished by
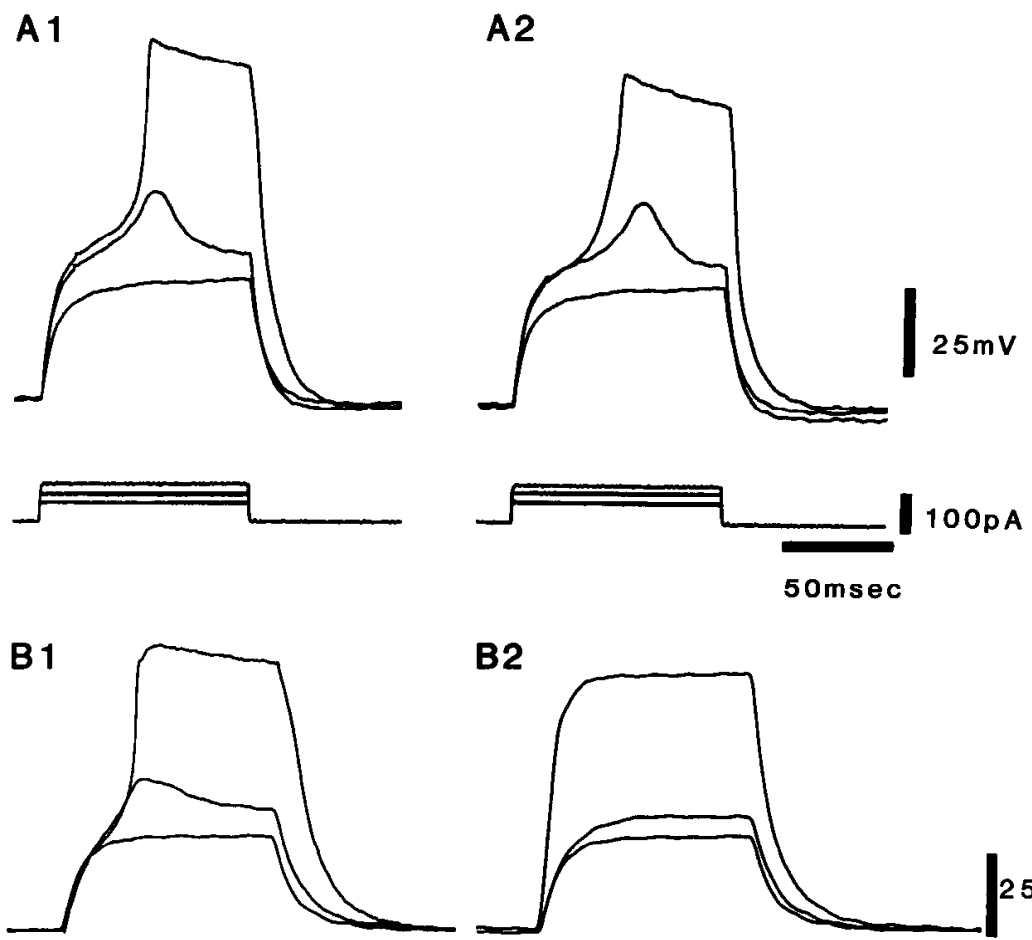

B2
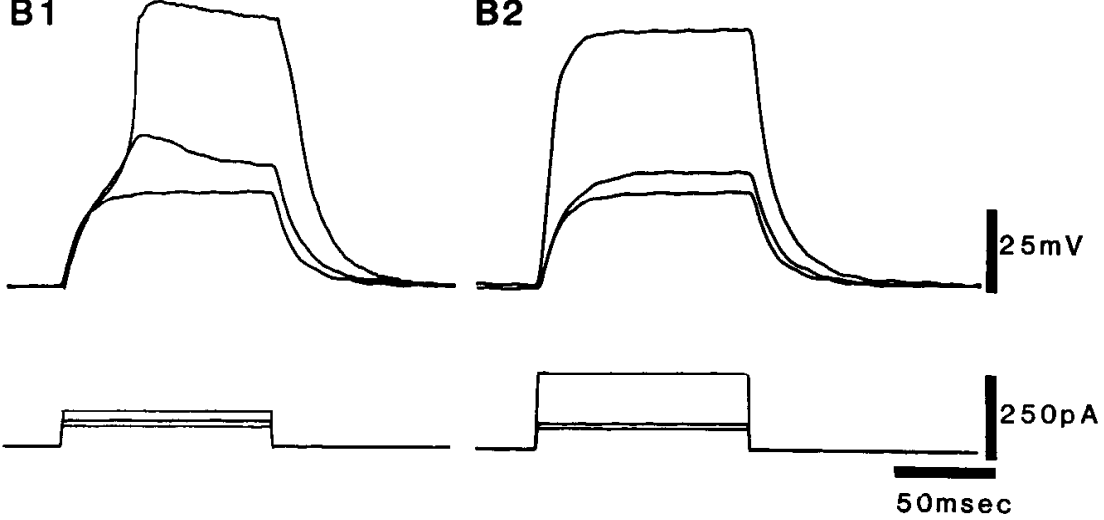

Figure 4. HTS and LTS are $\mathrm{Ca}^{2+}-\mathrm{de}-$ pendent spikes. Al, Following pharmacological blockade of $\mathrm{Na}^{+}$and $\mathrm{K}^{+}$ conductances as described in Figure 3, two $\mathrm{Ca}^{2+}$ spikes can again be seen. $A 2$, Addition of $3 \mu \mathrm{M}$ TTX to the extracellular solution had no effect on either spike. $B I$, In a second cell, similarly impaled, 2 spikes are again apparent. $B 2$, The addition of $1 \mathrm{~mm} \mathrm{Co} \mathrm{Co}^{2+}$ abolished both HTS and LTS. 


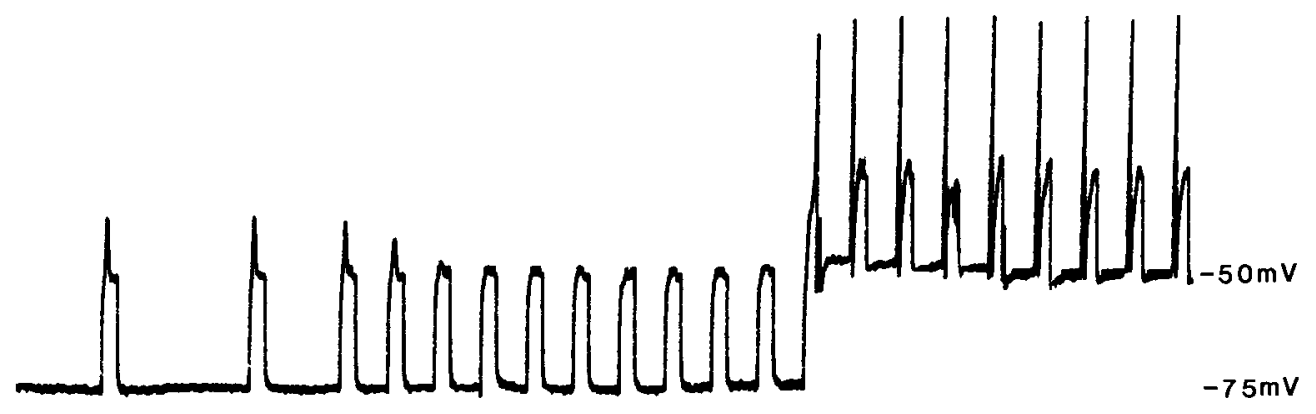

Figure 5. LTS and HTS inactivate at different rates. From a holding potential of $-75 \mathrm{mV}$ constant-current pulses $(80 \mathrm{pA})$ elicited the LTS. As the rate of delivery of pulses was increased from 0.5 to $2.0 \mathrm{~Hz}$, the LTS inactivated. The holding potential was then adjusted to $-50 \mathrm{mV}$, a potential which allowed the 80 pA pulse to activate the HTS. HTS was readily evoked when pulses were delivered at a rate of $2 \mathrm{~Hz}$ and could be evoked at rates up to $10 \mathrm{~Hz}$ (data not shown).

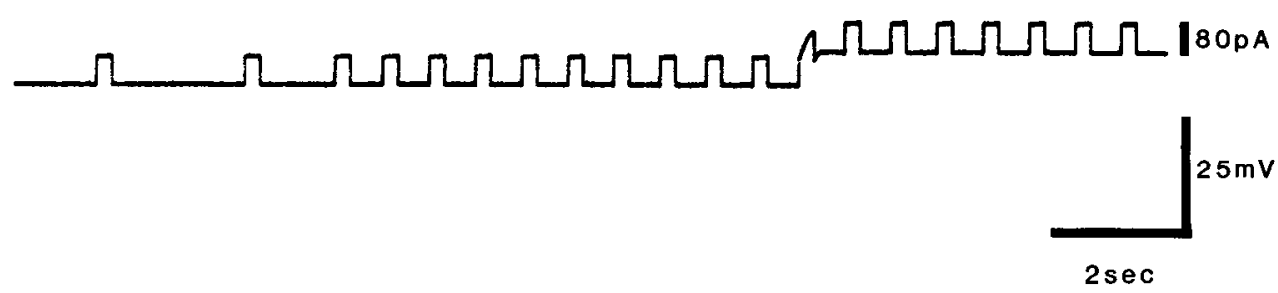

bath-applied TTX ( $n=3$, Fig. $4 A$ ), but both were abolished by $1 \mathrm{mM} \mathrm{Co}^{2+}$ (Fig. 4B), confirming their identity as $\mathrm{Ca}^{2+}$-dependent action potentials. As well as their differing activation thresholds, the LTS and HTS had different properties when activated repetitively (Fig. 5). The LTS quickly inactivated when pulses were delivered at rates above $0.5 \mathrm{~Hz}$, but the HTS could be evoked at rates of up to $10 \mathrm{~Hz}$.

In 80 cells, $\mathrm{Ca}^{2+}$ electrogenesis was analyzed further using single-electrode voltage-clamp techniques to examine currents underlying $\mathrm{Ca}^{2+}$-based action potentials. $\mathrm{Na}^{+}$and $\mathrm{K}^{+}$currents were abolished as described above. Current responses to step voltage command pulses were first obtained in control solution and then in solution containing $1 \mathrm{mM} \mathrm{Co}^{2+}$. The currents recorded in $\mathrm{Co}^{2+}$-containing solution were then subtracted from currents recorded in control. The resulting data in this report thus represent $\mathrm{Ca}^{2+}$-dependent currents abolished by $1 \mathrm{mM} \mathrm{Co}{ }^{2+}$. $\mathrm{Ca}^{2+}$ current records from a single cell are shown in Figure 6A, while averaged data from 9 cells are plotted in Figure $6 B$.

When cells were held at $-90 \mathrm{mV}$, step voltage command pulses to potentials between -70 and $+40 \mathrm{mV}$ revealed 2 distinct inward $\mathrm{Ca}^{2+}$ currents that were maximal at different potentials (Fig. 6). A small inactivating current appeared at test potentials above $-40 \mathrm{mV}$ and corresponds to a plateau in the current-voltage plot between -40 and $-25 \mathrm{mV}$ (Fig. 6B). A second larger current with a somewhat slower inactivation time was activated at more depolarized potentials and was maximal around $0 \mathrm{mV}$. When the cell was held at $-40 \mathrm{mV}$ (Fig. 6A) or $-30 \mathrm{mV}$ (Figs. 6B,7), test pulses to $0 \mathrm{mV}$ elicited a noninactivating current with a lower amplitude than was obtained from a $-90 \mathrm{mV}$ holding potential. This suggests that an inactivating portion of the current was abolished when the cell was held above $-40 \mathrm{mV}$. Further experiments were carried out to more clearly define the nature of the inactivating current.

The initial protocol was to hold the cell at $-90 \mathrm{mV}$, then shift the holding potential to $-30 \mathrm{mV}$ and begin applying $200 \mathrm{msec}$ command pulses to $0 \mathrm{mV}$ at $2 \mathrm{sec}$ intervals. In Figure 7 the initial pulse elicited $2 \mathrm{sec}$ after the shift to the $-30 \mathrm{mV}$ holding potential produced an initial transient current followed by a more sustained current. As the cell was held at $-30 \mathrm{mV}$, the transient current induced by subsequent test pulses declined until, after $12 \mathrm{sec}$, only a sustained, noninactivating current remained. When $\mathrm{Ca}^{2+}$ currents were evoked at $0.5 \mathrm{~Hz}$ from a holding potential of $-90 \mathrm{mV}$, this pattern of inactivation was not seen, and peak current amplitude was constant over many minutes $(n=25)$. The effect of nifedipine, a dihydropyridine which inhibits L-type $\mathrm{Ca}^{2+}$ currents, was also tested (Fig. 8). Nifedipine, $10 \mu \mathrm{M}$ (Bean, 1984; Meier et al., 1988), had little effect on peak currents evoked from a holding potential of -90 $\mathrm{mV}$ (peak current, $94 \pm 4 \%$ of control; mean $\pm \mathrm{SD}, n=5$ ) but strongly inhibited currents evoked from $-30 \mathrm{mV}$ (peak current, $42 \pm 12 \%$ of control; mean $\pm \mathrm{SD}, n=5$ ).

In an additional protocol, test pulses from -90 to $0 \mathrm{mV}$ were elicited $150 \mathrm{msec}$ after a prepulse of $200 \mathrm{msec}$ to potentials between -70 and $+70 \mathrm{mV}$. As can be seen in Figure $9 A$, the peak current was reduced significantly following a prepulse to $+10 \mathrm{mV}(n=13)$. The current that remained following the prepulse declined only slightly during a $400 \mathrm{msec}$ pulse and appears to be a noninactivating $\mathrm{Ca}^{2+}$ current. The magnitude of inhibition of peak current was dependent on the voltage of the prepulse (Fig. 9B). The maximal inhibition (70\%) occurred at a prepulse potential between +10 and $+30 \mathrm{mV}$. As the prepulse potential was made more positive, the inhibition of peak current was reduced. With a prepulse to $+70 \mathrm{mV}$, only a $20 \%$ reduction in peak current is seen compared with $70 \%$ reduction with a prepulse to $+10 \mathrm{mV}$. The prepulse potentials at which maximal inhibition of peak current occurs are in the same range as those which evoke maximal $\mathrm{Ca}^{2+}$ current, which suggests that $\mathrm{Ca}^{2+}$ entry, rather than voltage alone, may be responsible for the inactivation of peak $\mathrm{Ca}^{2+}$ currents.

\section{Discussion}

In order to fully understand the effects of synaptic activation on the cells of the PI, it is necessary to first characterize the ionic conductances present in the melanotroph. A number of 
A
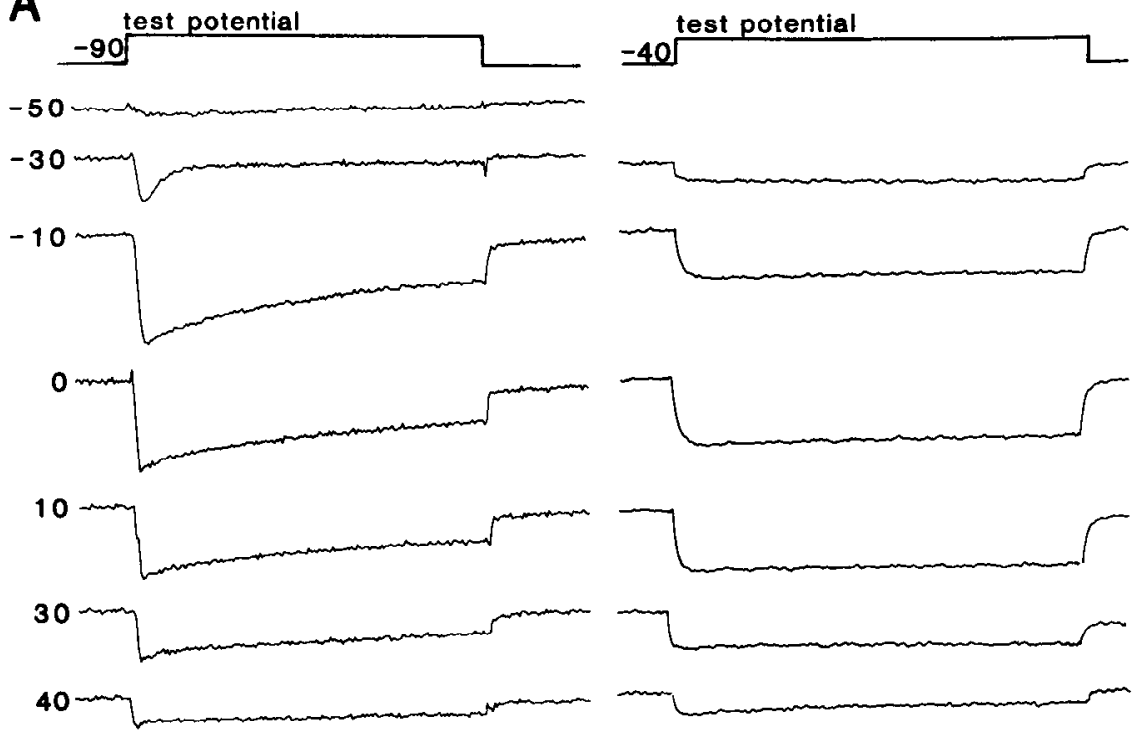

B

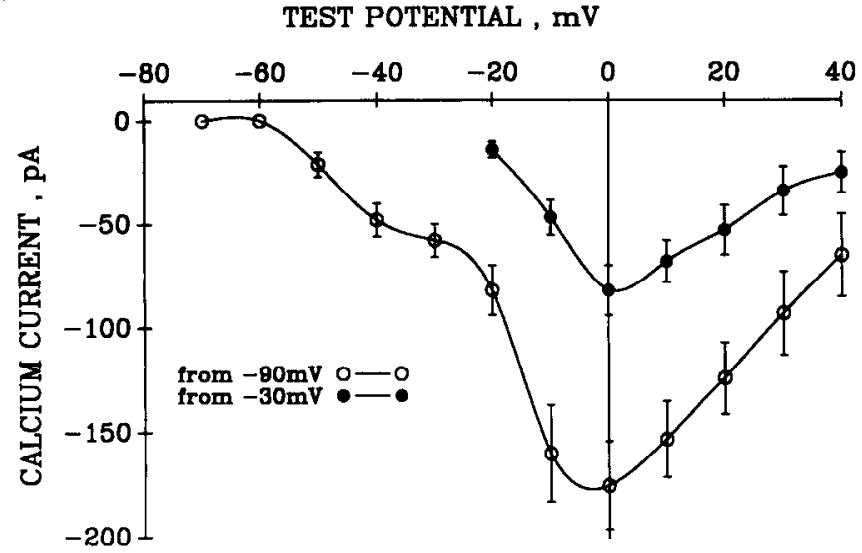

Figure 6. $A, \mathrm{Ca}^{2+}$ currents elicited from different holding potentials ( 90 or 40 $\mathrm{mV}$ ) to test potentials indicated by the values to the left of each trace. The currents illustrated here and in subsequent figures are the differences between currents activated by identical voltage steps in control solution and in solution containing $1 \mathrm{mM} \mathrm{Co}^{2+}$. They therefore represent the $\mathrm{Co}^{2+}$-sensitive $\mathrm{Ca}^{2+}$ current. From a holding potential of $-90 \mathrm{mV}$ (left), pulses to $-30 \mathrm{mV}$ produced a small transient current, while pulses to $0 \mathrm{mV}$ and more positive potentials produced a large current that decayed more slowly. The extent of the decay of the current during the pulses was reduced as the test potential increased from 0 to $+30 \mathrm{mV}$. When the voltage pulses were elicited from a holding potential of -40 $\mathrm{mV}$ (right), the peak current amplitude was reduced relative to a pulse to the same voltage from $-90 \mathrm{mV}$ and the current showed virtually no decay during the $200 \mathrm{msec}$ pulse. $B$, Averaged data (mean $\pm \mathrm{SEM}, n=9$ ) shows 3 types of $\mathrm{Ca}^{2+}$ current. $\mathrm{Ca}^{2+}$ currents are plotted against step voltage potential from a holding potential of $-90 \mathrm{mV}$ (open circles) or from $-30 \mathrm{mV}$ (filled circles). From a holding potential of -90 $\mathrm{mV}$, a small current activated at potentials of about $-50 \mathrm{mV}$ and peaked at $-30 \mathrm{mV}$. A second component of the current activated at $-20 \mathrm{mV}$ and peaked at $0 \mathrm{mV}$. From a holding potential of $-30 \mathrm{mV}$, only a single component was seen that peaked at about $0 \mathrm{mV}$. The difference between the 2 curves represents the current that was inactivated at a holding potential of $-30 \mathrm{mV}$. reports on the electrophysiology of the melanotroph have appeared (Douglas and Taraskevich, 1980, 1982, 1985). It has been shown, however, that ion channel distribution and properties may change after as little as a few days in culture (Cota and Armstrong, 1987). Our goal in these experiments therefore was to study the electrophysiology of cells in the intact PI within 1-3 $\mathrm{hr}$ of isolation from the animal. This preparation has the advantage of retaining intact DA and GABAergic innervation, as well as preventing any changes in the melanotroph related to the culturing process. This is particularly important in the study of $\mathrm{Ca}^{2+}$ currents, since Fox et al. (1987a) have shown that major alterations in the ratio of $\mathrm{T}-, \mathrm{N}$-, and L-type currents in chick dorsal root ganglion (DRG) neurons can occur when these cells are cultured in different media.

The cells of the PI are small and cuboid in appearance and are devoid of processes. The results of our study with Lucifer yellow also suggest that these cells are not electrically coupled, based on the absence of dye coupling. It is thus relatively straight forward to ensure adequate space clamp of these cells as mem- brane potential variations in distant dendritic processes are not a problem. The simplicity of the PI anatomy and the monosynaptic nature of the DA and GABAergic inputs (Howe, 1973) greatly simplifies the interpretation of results and also provides potential for the future analysis of synaptic currents in these cells.

Recordings from the intact PI showed that a percentage of the melanotrophs display spontaneous $\mathrm{Na}^{+}$-dependent action potentials. This finding is similar to that reported by Douglas and Taraskevich (1980) in cultured rat melanotrophs. The action potentials could be blocked by external TTX or by intracellular application of the local anesthetic QX-222. The blockade by QX-222 is useful in that it now becomes possible to eliminate $\mathrm{Na}^{+}$currents in the cell under study without blocking action potentials in the neurons innervating the PI. The specificity of lidocaine-derived anesthetics for $\mathrm{Na}^{+}$currents and, in particular, its lack of effect on $\mathrm{Ca}^{2+}$-dependent responses has been shown by others (Connors and Prince, 1982, and references therein). It is also possible to block all $\mathrm{K}^{+}$conductances in order 
Figure 7. One component of the $\mathrm{Ca}^{2+}$ current inactivates at $-30 \mathrm{mV}$. Holding potential was initially maintained at $-90 \mathrm{mV}$ and then rapidly stepped to a new holding potential of $-30 \mathrm{mV}$. Two seconds after attaining the new potential, $200 \mathrm{msec}$ pulses to $0 \mathrm{mV}$ were delivered at a rate of $0.5 \mathrm{~Hz}$. The figure shows the sequential responses to 6 such pulses over a $12 \mathrm{sec}$ period. The inactivating component of the current rapidly declined, whereas the noninactivating component was more stable.

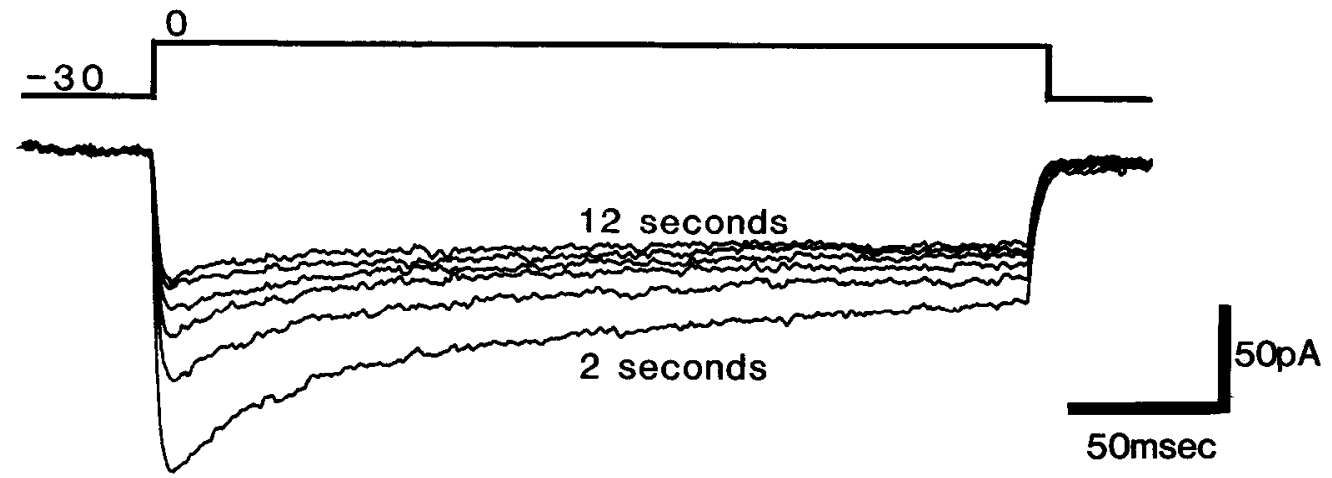

to study $\mathrm{Ca}^{2+}$ currents by including 4-AP in the extracellular medium and by using electrodes containing $0.5 \mathrm{M} \mathrm{Cs}^{+}$acetate and $50 \mu \mathrm{M}$ TEA acetate.

Conventional intracellular recording revealed the presence of $2 \mathrm{Ca}^{2+}$ spikes in the melanotroph, one (HTS) activated at more depolarized potentials above $-20 \mathrm{mV}$, the other (LTS) activated at more hyperpolarized potentials positive to $-40 \mathrm{mV}$. Voltageclamp recording allowed the analysis of $\mathrm{Ca}^{2+}$ currents underlying these potentials. One transient current activated at test potentials above $-40 \mathrm{mV}$ and was completely inactivated at holding potentials above $-50 \mathrm{mV}$. This current appears to correspond to the LTS. A second current was activated at test potentials above $-20 \mathrm{mV}$ and showed both transient and sustained components when activated from $-90 \mathrm{mV}$. This current appears to underlie the HTS. It has recently been suggested that only 2 types of $\mathrm{Ca}^{2+}$ currents are present in the melanotroph (Stanley and Russel, 1988). Our data, however, support the concept (Taleb et al., 1986) that there are 3 distinct components to the current, although we are unable to determine whether these components represent separate $\mathrm{Ca}^{2+}$ channels. The major question seems to be whether the HTS consists of 1 or 2 components; our data suggest that there are 2 currents. Currents activated by pulses to $0 \mathrm{mV}$ from a holding potential of $-90 \mathrm{mV}$ show significant inactivation during a $200 \mathrm{msec}$ pulse and have a greater amplitude than currents elicited by pulses to the same potential from a holding potential of $-30 \mathrm{mV}$. This suggests that one component of the current activated from $-90 \mathrm{mV}$ is inactivated when the cell is held at $-30 \mathrm{mV}$, and the experiments illustrated in Figure 7 show the nature and time course of this inactivation. Similarly, short prepulses to positive potentials reduce the amplitude of the current evoked by a subsequent test pulse to $0 \mathrm{mV}$. The current that remains following maximal inhibition by the prepulse is nonactivating. Taken together, these results suggest that the HTS is due to 2 currents, onc transient current that is inactivated when the cell is held above $-30 \mathrm{mV}$ and another sustained current that is unaffected by more positive holding potentials.

It is possible that the inactivation of the high-threshold transient current may be $\mathrm{Ca}^{2+}$ dependent. The inhibition of this current by prepulses is maximal at a prepulse amplitude of 0 to $+20 \mathrm{mV}$, which is similar to the potential range at which $\mathrm{Ca}^{2+}$ currents are maximal. Inactivation is reduced at more positive potentials, where the total $\mathrm{Ca}^{2+}$ current is reduced as prepulse potential approaches the $\mathrm{Ca}^{2+}$ equilibrium potential. Recently, other authors have reported a similar pattern of peak $\mathrm{Ca}^{2+}$ current inhibition by prepulses in NG108-15 cells (Docherty, 1988) and in frog melanotroph (Louiset et al., 1988). This raises the question of the identity of the inactivating current since other high-threshold inactivating currents in DRG showed voltage, rather than $\mathrm{Ca}^{2+}$-based, inactivation (Fox et al., 1987a, b).
Figure 8. Nifedipine blocks the L-type current. $\mathrm{Ca}^{2+}$ currents in response to pulses from a holding potential of -90 or $-30 \mathrm{mV}$ to the values indicated by the points are plotted against the potential of the test pulse. Values were obtained in control solution and following addition of $10 \mu \mathrm{M}$ nifedipine. Addition of nifedipine has no effect on currents elicited from a holding potential of $-90 \mathrm{mV}$ but significantly reduces currents from a holding potential of -30 $\mathrm{mV}$.

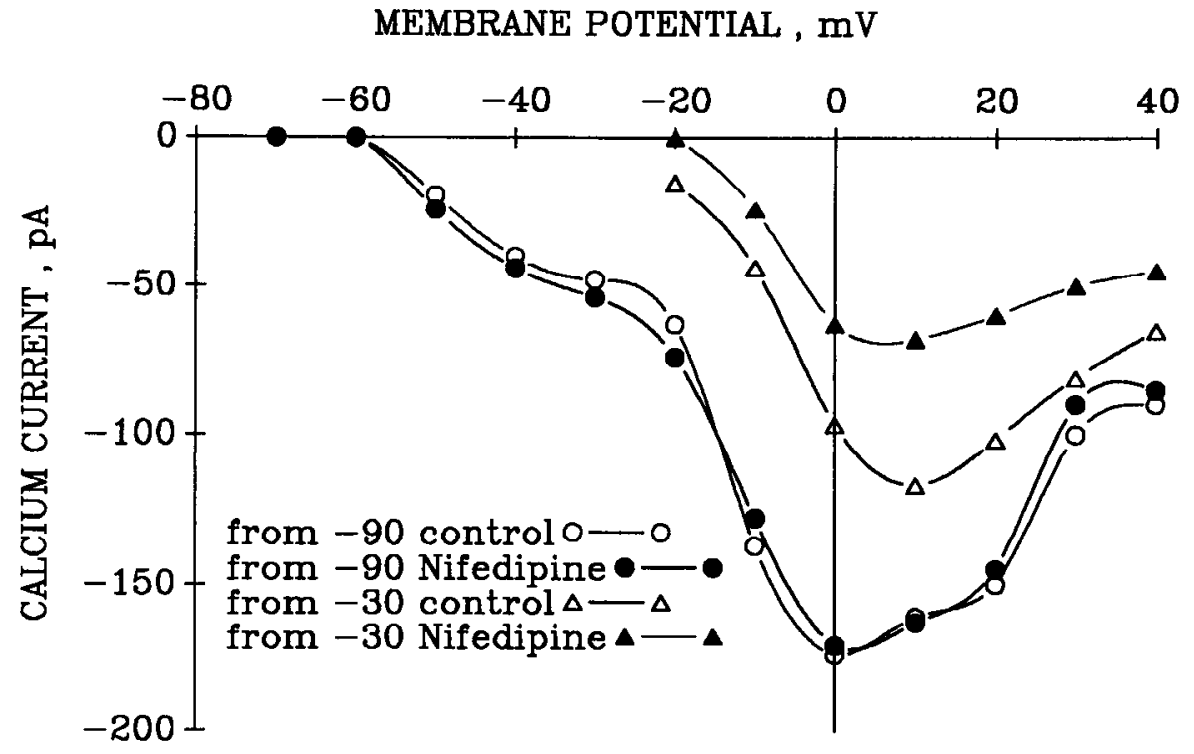


The model proposed by Nowycky et al. (1985) identified 3 different $\mathrm{Ca}^{2+}$ currents based primarily on activation and inactivation characteristics. In their formulation, the low-threshold transient current is designated the T-type, the high-threshold noninactivating current is the L-type, and the high-threshold transient current is the $\mathrm{N}$-type. The currents that we have described in the melanotroph fit into these 3 classes based on activation and inactivation criteria. An additional criteria which has been used to identify L-type channel is their sensitivity to dihydropyridines. The high-threshold, noninactivating current described here would thus be classified as an L-type channel based on its inhibition by nifedipine. It has been shown that dihydropyridines do not bind with high affinity to $\mathrm{Ca}^{2+}$ channels at hyperpolarized potentials (Bean, 1984). The lack of effect of nifedipine on $\mathrm{Ca}^{2+}$ currents elicited from $-90 \mathrm{mV}$ may be due to this phenomenon; however, the relatively high dose of nifedipine $(10 \mu \mathrm{M})$ would be adequate to overcome the effects of the low membrane potential, and Fox et al. (1987a) have shown that nifedipine at this concentration does not affect $\mathrm{N}$-type $\mathrm{Ca}^{2+}$ channels in chick DRG neurons. The inactivating high-threshold current which is resistant to nifedipine would thus be classificd as an N-type. A number of authors have identified $\mathrm{Ca}^{2+}$ channels which do not fit into the $T, N$, and $L$ classification scheme (Kinnamon et al., 1989; Llinás et al., 1989; Plummer et al., 1989); indeed, Tsien, one of the original proponents of the model, has suggested that there may be "families" of currents with slightly different properties within the $T, N$, and $L$ classes (Tsien et al., 1988).

Our observations suggest that the $\mathrm{N}$-type current in the melanotroph is not identical to the current described in chick DRG (Fox et al., 1987a, b) in that it may be subject to $\mathrm{Ca}^{2+}$-dependent inactivation. It is possible that the N-type currents in DRG and melanotroph represent different subtypes of this current. In view of the similarities between the high-threshold transient current reported here and that described by others (Tsien et al., 1988), it would seem reasonable to continue to designate the highthreshold inactivating current in the melanotroph as N-type at this time. Further investigation of the ionic dependence of the current is in progress and will provide additional clarification of this complex situation.

The roles that these $\mathrm{Ca}^{2+}$ channels play in the functioning of the $\mathrm{PI}$ remains to be elucidated. It has been suggested that $\mathrm{T}$-type currents are involved in the control of firing rate in spontaneously active cells (Llinás and Yarom, 1981; Jahnsen and Llinás, 1984), and their presence in the melanotroph would be consistent with the spontaneous discharge pattern of these cells (Williams et al., 1989b). L-type currents have been associated with the transduction of membrane depolarization into an intracellular $\mathrm{Ca}^{2+}$ signal triggering some cellular response (McCleskey et al., 1986). Hormone release may be an example of such a response, and $\alpha \mathrm{MSH}$ release has been shown to be $\mathrm{Ca}^{2+}$ dependent in these cells (Thornton, 1982) and to be increased by dihydropyridine $\mathrm{Ca}^{2+}$ channel agonists (Taraskevich and Douglas, 1986). The role of the N-type current is less clear since it has been suggested that the $\mathrm{N}$-type current is seen only in neuronal membranes where it plays a role in neurotransmitter release (Fox et al., 1987a, b; Hirning et al., 1988). Although the melanotroph is classed as a neuroendocrine cell, it shows many similarities with neurons. This is especially true in terms of the variety of ion channels expressed in the melanotroph and the presence of spontaneous $\mathrm{Na}^{+}$-bascd action potentials. It has also been suggested (Douglas and Taraskevitch, 1985) that the PI
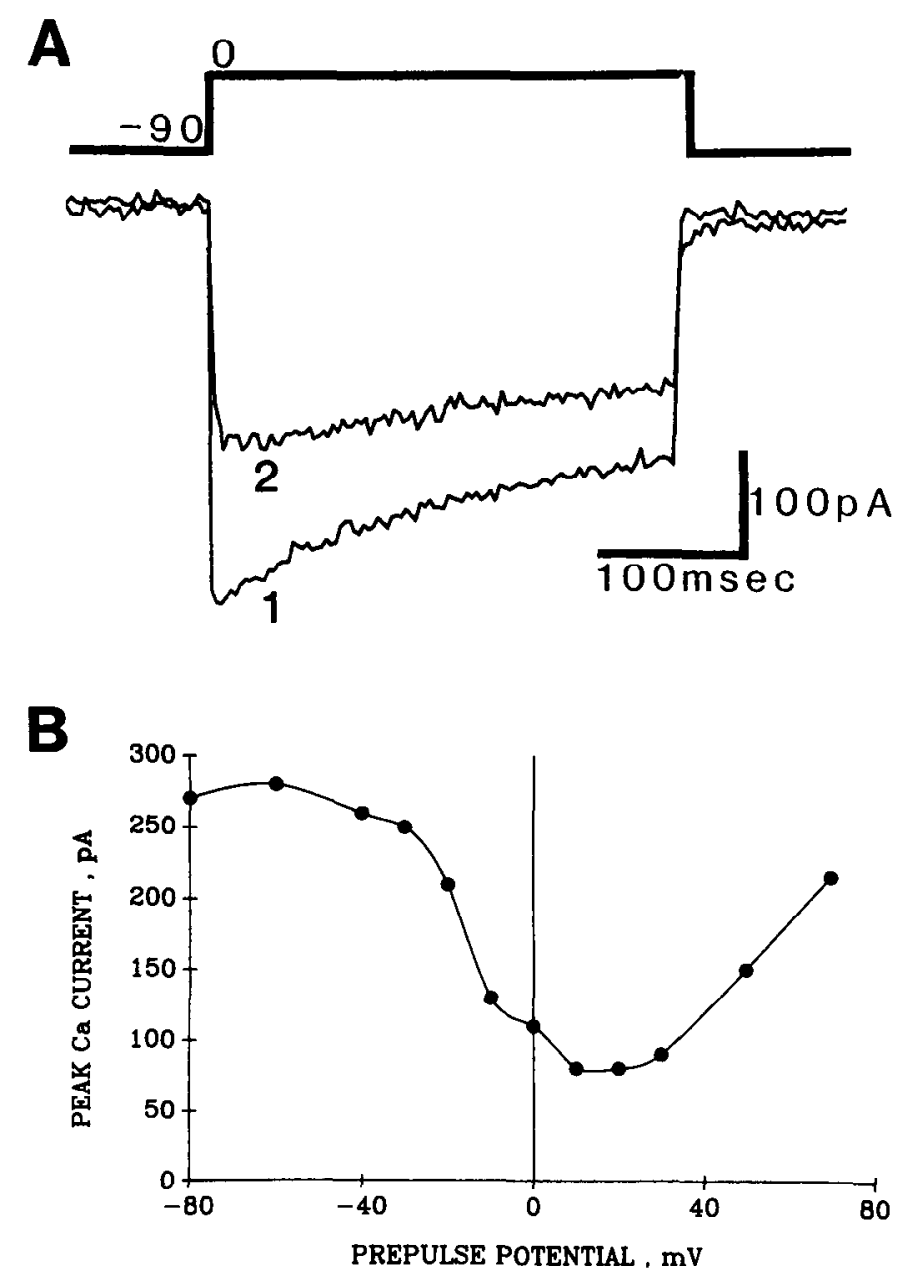

Figure 9. $A, \mathrm{Ca}^{2+}$ currents are reduced by a prepulse to positive potentials. Control current response $(l)$ was obtained in response to a voltage step from -90 to $0 \mathrm{mV}$. When a $200 \mathrm{msec}$ prepulse to +10 $\mathrm{mV}$ was delivered $150 \mathrm{msec}$ prior to the voltage step (2), the magnitude of the current is decreased and the decay of the current during the pulse is less pronounced. $B$, Effects of prepulse potential on peak current. Currents similar to those in $A$ were produced by pulses from a holding potential of $-90 \mathrm{mV}$ to a test potential of $0 \mathrm{mV}$. Test pulses were preceded by prepulse to the voltage shown by the data points. The prepulse was $200 \mathrm{msec}$ long and occurred $150 \mathrm{msec}$ prior to the test pulse. The magnitude of the current evoked by the test pulse is reduced as the prepulse potential increases, reaches a minimum value at prepulse potentials between +10 and $+20 \mathrm{mV}$, and then returns toward control values as the prepulse potential increases to $+70 \mathrm{mV}$.

and the neurons of the hypophysis are derived from a common embryonic precursor, the neuroectoderm. These similarities may explain the presence of the N-type current in the melanotroph, while it is apparently not seen in other non-neuronal tissue.

\section{References}

Bean, B. (1984) Nitrendipine block of cardiac calcium channels: High affinity binding to the inactivated state. Proc. Natl. Acad. Sci. USA 81: 6388-6392.

Connors, B. W., and D. A. Prince (1982) Effects of QX-314 on the membrane properties of hippocampal pyramidal neurons. J. Pharmacol. Exp. Ther. 220: 476-481.

Cota, G. (1986) Calcium channel currents in pars intermedia cells of the rat pituitary gland. J. Gen. Physiol. 88: 83-105.

Cota, G., and C. M. Armstrong (1987) Long term stimulation of dopamine receptors inhibits calcium channel activity in cultured pituitary cells. Soc. Neurosci. Abstr. 13: 794. 
Docherty, R. J. (1988) Gadolinium selectively blocks a component of calcium current in rodent neuroblastoma $\times$ glioma hybrid (NG10815) cells. J. Physiol. (Lond.) 398: 33-47.

Douglas, W. W., and P. S. Taraskevich (1980) Calcium component to action potentials in rat pars intermedia cells. J. Physiol. (Lond.) 309: 623-630.

Douglas, W. W., and P. S. Taraskevich (1982) Slowing effects of dopamine and calcium-channel blockers on frequency of sodium spikes in rat pars intermedia cells. J. Physiol. (Lond.) 326: 201-211.

Douglas, W. W., and P. S. Taraskevich (1985) The electrophysiology of adenohypophyseal cells. In The Electrophysiology of the Secretory Cell, Poisner and Trifaro, eds., pp. 63-92, Elsevier, New York.

Fox, A. P., M.C. Nowycky, and R. W. Tsien (1987a) Kinetic and pharmacological properties distinguishing three types of calcium currents in chick sensory neurons. J. Physiol. (Lond.) 394: 149-172.

Fox, A. P., M. C. Nowycky, and R. W. Tsien (1987b) Single channel recordings of three types of calcium channel in chick sensory neurons. J. Physiol. (Lond.) 394: 173-200.

Goldman, M. E., M. Beaulieu, J. W. Kebabian, and R. L. Eskay (1983) $\alpha$-Melanocyte stimulating hormone-like peptides in the intermediate lobe of the rat pituitary gland: Characterization of content and release in vitro. Endocrinology 112: 435-441.

Hirning, L. D., A. P. Fox, E. W. McCleskey, B. M. Olivera, S. A. Thayer, R. J. Miller, and R. W. Tsien (1988) Dominant role of N-type calcium channels in evoked release of norepinephrine from sympathetic neurons. Science 239: 57-61.

Howc, A. (1973) The mammalian pars intermedia: A review of its structure and function. J. Endocrinol. 59: 385-409.

Jahnsen, H., and R. Llinás (1984) Electrophysiological properties of guinea-pig thalamic neurons: An in vitro study. J. Physiol. (Lond.) 344: 205-226.

Kinnamon, S. C., T. A. Cummings, S. D. Roper, and K. G. Beam (1989) Calcium currents in isolated taste receptor cells of the mudpuppy. Ann. NY Acad. Sci. 560: 112-115.

Llinás, R., and Y. Yarom (1981) Electrophysiology of mammalian inferior olivary neurons in vitro. Different types of voltage dependent ionic conductances. J. Physiol. (Lond.) 315: 549-567.

Llinás, R. R., M. Sugimori, and B. Cherksey (1989) Voltage dependent calcium conductances in mammalian neurons: The P channel. Ann. NY Acad. Sci. 560: 103-111.

Louiset, E., L. Cazin, M. Lamacz, M. C. Tonon, and H. Vaudry (1988) Patch clamp study of ionic currents underlying action potentials in cultured frog pituitary melanotrophs. Neuroendocrinology 48: 507515.
MacVicar, B. A., and Q. J. Pittman (1986) Novel synaptic responses mediated by dopamine and $\gamma$-aminobutyric acid in neuroendocrine cells of the intermediate pituitary. Neurosci. Lett. 64: 35-40.

McCleskey, E. W., A. P. Fox, D. Feldman, and R. W. Tsien (1986) Different types of calcium channels. J. Exp. Biol. 124: 177-190.

Meier, K., W. Knepel, and C. Schöfl (1988) Potassium depolarization elevates cytosolic free calcium concentration in rat anterior pituitary cells through 1,4-dihydropyridine-sensitive, $\omega$-conotoxin insensitive calcium channels. Endocrinology 122: 2764-2770.

Nowycky, M. C., A. P. Fox, and R. W. Tsien (1985) Three types of neuronal calcium channels with different calcium agonist sensitivity. Nature 316: 440-443.

Plummer, M. R., D. E. Logothetis, and P. Hess (1989) Components of calcium current in differentiated $\mathrm{PCl} 2$ cells and neonatal rat sympathetic neurons. Biophys. J. 55: 437a.

Puil, E., and P. L. Carlen (1984) Attenuation of glutamate action, excitatory postsynaptic potentials and spikes by intracellular QX-222 in hippocampal neurons. Neuroscience 11:389-398.

Stanley, E. F., and J. T. Russel (1988) Inactivation of calcium channels in rat pituitary intermediate lobe cells. Brain Res. 475: 64-72.

Taleb, O., J. Trouslard, B. A. Demeneix, and P. Feltz (1986) Characterization of calcium and sodium currents in porcine pars intermedia cells. Neurosci. Lett. 66: 55-60.

Taraskevich, P. S., and W. W. Douglas (1986) Effects of BAY K8644 and other dihydropyridines of basal and potassium evoked output of MSH from mouse melanotrophs in vitro. Neuroendocrinology 44 : 384-389.

Thornton, V. F. (1982) Stimulation of calcium-dependent release of labelled protein from pulse-labelled mouse pituitary intermediate lobe tissue. J. Physiol. (Lond.) 329: 425-437.

Tsien, R. W., D. Lipscombe, D. V. Madison, K. R. Bley, and A. P. Fox (1988) Multiple types of neuronal calcium channels and their selective modulation. Trends Neurosci. 11: 431-438.

Williams, P. J., B. A. MacVicar, and Q. J. Pittman (1989a) Identifcation of GABA-activated chloride mediated synaptic potential in rat pars intermedia. Brain Res. 483: 130-134.

Williams, P. J., B. A. MacVicar, and Q. J. Pittman (1989b) A dopaminergic IPSP mediated by an increased potassium conductance. Neuroscience 31: 673-681.

Williams, P. J., B. A. MacVicar, and Q. J. Pittman (1990) Synaptic modulation by dopamine of calicum currents in rat pars intermedia. J. Neurosci. 10: 757-763. 